NASA/TM-2002-211483

The Effects of Substrate Material and Thermal Processing Atmosphere on the Strength of PS304: A High Temperature Solid Lubricant Coating

Christopher DellaCorte

Glenn Research Center, Cleveland, Ohio 
Since its founding, NASA has been dedicated to the advancement of aeronautics and space science. The NASA Scientific and Technical Information (STI) Program Office plays a key part in helping NASA maintain this important role.

The NASA STI Program Office is operated by Langley Research Center, the Lead Center for NASA's scientific and technical information. The NASA STI Program Office provides access to the NASA STI Database, the largest collection of aeronautical and space science STI in the world. The Program Office is also NASA's institutional mechanism for disseminating the results of its research and development activities. These results are published by NASA in the NASA STI Report Series, which includes the following report types:

- $\quad$ TECHNICAL PUBLICATION. Reports of completed research or a major significant phase of research that present the results of NASA programs and include extensive data or theoretical analysis. Includes compilations of significant scientific and technical data and information deemed to be of continuing reference value. NASA's counterpart of peerreviewed formal professional papers but has less stringent limitations on manuscript length and extent of graphic presentations.

- TECHNICAL MEMORANDUM. Scientific and technical findings that are preliminary or of specialized interest, e.g., quick release reports, working papers, and bibliographies that contain minimal annotation. Does not contain extensive analysis.

- CONTRACTOR REPORT. Scientific and technical findings by NASA-sponsored contractors and grantees.
- CONFERENCE PUBLICATION. Collected papers from scientific and technical conferences, symposia, seminars, or other meetings sponsored or cosponsored by NASA.

- SPECIAL PUBLICATION. Scientific, technical, or historical information from NASA programs, projects, and missions, often concerned with subjects having substantial public interest.

- TECHNICAL TRANSLATION. Englishlanguage translations of foreign scientific and technical material pertinent to NASA's mission.

Specialized services that complement the STI Program Office's diverse offerings include creating custom thesauri, building customized databases, organizing and publishing research results ... even providing videos.

For more information about the NASA STI Program Office, see the following:

- Access the NASA STI Program Home Page at http://www.sti.nasa.gov

- E-mail your question via the Internet to help@sti.nasa.gov

- Fax your question to the NASA Access Help Desk at 301-621-0134

- Telephone the NASA Access Help Desk at 301-621-0390

- Write to:

NASA Access Help Desk

NASA Center for AeroSpace Information 7121 Standard Drive

Hanover, MD 21076 
NASA/TM-2002-211483

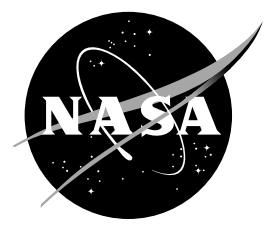

The Effects of Substrate Material and Thermal Processing Atmosphere on the Strength of PS304: A High Temperature Solid Lubricant Coating

Christopher DellaCorte

Glenn Research Center, Cleveland, Ohio

National Aeronautics and

Space Administration

Glenn Research Center 
The Aerospace Propulsion and Power Program at NASA Glenn Research Center sponsored this work.

Trade names or manufacturers' names are used in this report for identification only. This usage does not constitute an official endorsement, either expressed or implied, by the National Aeronautics and Space Administration.

Available from

NASA Center for Aerospace Information 7121 Standard Drive

Hanover, MD 21076
National Technical Information Service 5285 Port Royal Road Springfield, VA 22100

Available electronically at http:/ /gltrs.grc.nasa.gov 


\title{
The Effects of Substrate Material and Thermal Processing Atmosphere on the Strength of PS304: A High Temperature Solid Lubricant Coating
}

\author{
Christopher DellaCorte \\ National Aeronautics and Space Administration \\ Glenn Research Center \\ Cleveland, Ohio 44135
}

\begin{abstract}
Summary
PS304, a plasma spray deposited solid lubricant coating developed for high temperature sliding contacts was deposited on nine different substrate metals, heat treated at $650{ }^{\circ} \mathrm{C}$ in either air or argon and subsequently tested for strength using a commercially available pull-off adhesion test. Some samples were examined metallographically to help elucidate and explain the results.

As deposited coatings exhibit pull-off strengths typically between 16 and $20 \mathrm{MPa}$ with failure occurring (cohesively) within the coating. Heat treatment in argon at $650{ }^{\circ} \mathrm{C}$ results in a slight increase in coating (cohesive) strength of about 30 percent to 21 to $27 \mathrm{MPa}$. Heat treatment in air at $650{ }^{\circ} \mathrm{C}$ results in a dramatic increase in strength to over $30 \mathrm{MPa}$, exceeding the strength of the epoxy used in the pull test. Cross section metallographic analyses show that no microstructural coating changes occur following the argon heat treatments, however, exposure to air at $650{ }^{\circ} \mathrm{C}$ gives rise to the formation of a second chromium-rich phase precipitate within the PS304 $\mathrm{NiCr}$ constituent which provides a strengthening effect and a slight ( $\sim 5$ percent) coating thickness increase. Subsequent heat treatments do not result in any further coating changes. Based upon these studies, PS304 is a suitable coating for use on a wide variety of high temperature substrates and must be heat treated following deposition to enhance strength and ensure dimensional stability.
\end{abstract}

\section{Introduction}

PS304 is a plasma sprayed high temperature solid lubricant coating developed at NASA Glenn Research Center to reduce friction and wear in sliding contacts encountered in many heat engines and industrial and aerospace mechanisms (refs. 1 and 2). PS304 is made by the plasma spray deposition of a powder blend comprised of $60 \mathrm{wt} \% \mathrm{NiCr}, 20 \mathrm{wt} \% \mathrm{Cr}_{2} \mathrm{O}_{3}$, and $10 \mathrm{wt} \%$ each of $\mathrm{BaF}_{2} / \mathrm{CaF}_{2}$ eutectic and silver. Each component plays a different functional role within the composite and the PS304 coating exhibits characteristics representing the summed properties of the individual constituents (ref. 3). For instance, the $\mathrm{NiCr}$ acts as a binder, the $\mathrm{Cr}_{2} \mathrm{O}_{3}$ acts as a dispersed hardening agent, the $\mathrm{BaF}_{2} / \mathrm{CaF}_{2}$ is a high temperature solid lubricant and silver is a low temperature solid lubricant. As a composite, PS304 exhibits low friction and wear properties over a wide range of temperatures and is suited for deposition onto a wide variety of substrate materials. Figure 1 shows a typical PS304 cross-section. PS304 has been found to be a suitable coating for many applications including Exhaust Gas Recirculation (EGR) and Turbocharger waste gate valve stems, foil air bearings and seals, steam turbine control valve components and bushings and shafting in heat treatment furnaces (ref. 4).

During its development, it has been observed that PS304 exhibits varying strength, measured through adhesion tests, depending upon substrate metal and thermal history. In addition, PS304 undergoes dimensional changes (thickness growth) following exposure to high temperature air environments (ref. 5). This paper reports on a systematic research effort to quantify the effects of substrate material and thermal processing on the strength, dimensional stability and microstructure of PS304. It is expected that an improved understanding of these attributes and effects will aid the transition of PS304 technology from the laboratory to commercial applications. 
To study these effects, nine different alloy substrate materials were coated with PS304. Some were heat treated for $100 \mathrm{hr}$ in air or argon followed by pull-type adhesion tests and subsequent metallographic analyses. A unique back-to-back specimen mounting technique was used to assess dimensional changes and standard SEM tools were employed to help understand microstructural changes within the coating.

\section{Materials and Procedures}

The primary test conducted in the program is a pull type adhesion test. Specimens were prepared by plasma-spray depositing PS304 approximately $250 \mu \mathrm{m}$ thick onto $6 \mathrm{~mm}$ thick, $25 \mathrm{~mm}$ diameter substrate coupons. PS304 is a NiCr based solid lubricant coating developed for friction and wear reduction in high temperature sliding contacts. Table I gives the nominal composition and properties of PS304. As shown in the table, the $\mathrm{NiCr}(60 \mathrm{wt} \%)$ acts as a wear resistant matrix with a $\mathrm{Cr}_{2} \mathrm{O}_{3}(20 \mathrm{wt} \%)$ hardening additive. Silver $(10 \mathrm{wt} \%)$ is added as a low temperature lubricant and $\mathrm{BaF}_{2} / \mathrm{CaF}_{2}$ eutectic $(10 \mathrm{wt} \%)$ is added for high temperature lubrication. The PS304 coating and its tribological and materials properties and deposition procedures are fully described in Refs. 1 to 4.

The substrate materials considered in this study were selected because they are typical high temperature structural materials or represent a particular candidate material class (e.g., Aluminum). The substrate alloys included: the superalloys Inconel 718, Stellite 6B; the stainless steels alloy 410, alloy 304, PH 13-8Mo and Greek Ascoloy; Ti6Al-4V a common Titanium alloy and $6061 \mathrm{Al}$ a high performance aluminum alloy. Table II lists the nominal composition of the substrate materials, their properties, and their general classes (e.g., precipitation hardened, austenitic, etc.).

Many of the PS304 coated specimens were subjected to various thermal processing prior to being adhesion tested. For example, some were exposed to air at $650{ }^{\circ} \mathrm{C}$ for $100 \mathrm{hr}$ while others were exposed to argon gas at $650{ }^{\circ} \mathrm{C}$ for $100 \mathrm{hr}$. Control examples, which were not heat-treated, were tested in the as-deposited state for comparison. Their heat treatments were selected based upon earlier published work for PS304 deposited on 13-8Mo stainless steel which conclusively showed that brief exposure ( $>24 \mathrm{hr})$ to air above $550{ }^{\circ} \mathrm{C}$ results in a complete heat treatment (ref. 5). At least six specimens were prepared for each substrate and each different exposure condition (i.e., argon, air or no exposure). Additionally, one extra specimen was specially prepared for metallographic examination without undergoing an adhesion test to quantify any dimensional or microstructural changes occurring during the heat treatment. This was accomplished by slicing (using wire Electrode Discharge Machining) the coated coupon into two equal semi-circular pieces. One half was heat treated with the six full adhesion test coupons. Its mating half was reserved without heat treatment for direct comparison. Figure 2 schematically shows how these metallurgical samples were prepared. By following this process an accurate comparison of exposed and unexposed coating/substrate can be made without coating variations (i.e., thickness, voids phases) interfering in the measurements. Since earlier work (ref. 5) showed that the PS304 coating undergoes a significant thickness increase following heat treatment, these semi-circular samples will also assist in quantifying and understanding the cause(s) of this growth. Titanium and Aluminum are not considered high temperature alloys. For these specimens, a lower temperature heat treatment $\left(593{ }^{\circ} \mathrm{C}\right)$ was employed but resulted in coating delamination upon cooling. No heat-treated adhesion data is provided for these samples.

The adhesion pull test for coating bond/strength is shown in figure 3. To prepare a specimen, a PS304 coated coupon (following its heat treatment) is glued to a threaded aluminum pull stud using a two-part epoxy. The epoxy glue was allowed to set at room temperature $\left(25^{\circ} \mathrm{C}\right)$ for $24 \mathrm{hr}$ and then was oven cured at a $70{ }^{\circ} \mathrm{C}$ for $24 \mathrm{hr}$ then cooled again to $25^{\circ} \mathrm{C}$. The threaded stud was then screwed into the piston of the pneumatically loaded pull test fixture. The air pressure was then increased at a constant rate resulting in a loading profile of approximately $50 \mathrm{Kgf} / \mathrm{sec}$. The air pressure, and hence pull-off load, was monitored continuously during the test. Upon failure, which always occurred suddenly, the pull-off pressure was automatically recorded and the pull-off strength was calculated. Each pull-off test lasted only about 30 seconds. The data reported in this paper represents over 200 pull-off tests. 


\section{Results and Discussion}

The test results are summarized in table III and depicted graphically in figures 4 to 6 . Figure 4 shows the pull-off data for the as-deposited PS304 on the eight substrate alloys. There appears to be a slight variation in strength depending upon the substrate. For example, when deposited on Inconel 718 the PS304 fails at 19.9 MPa while on Aluminum failure occurs at 16.3 MPa. Although the pull-stud test is considered an adhesion test, few if any of the specimens failed at the substrate coating interface. All of the samples (except occasionally Aluminum) failed inside the PS304 coating, a cohesive failure. As such, the pull-stud data is actually measuring PS304 cohesive strength or tensile strength not substrate-coating adhesion strength.

Following a heat treatment in air (fig. 5), the PS304 becomes much stronger. In fact, almost all of the samples exhibited strengths higher than the epoxy strength. Thus the strength plot for air heat-treated PS304 is essentially a horizontal line at about $35 \mathrm{MPa}$, the epoxy cohesive strength. Various glue strength enhancements were attempted. There included different heat cure procedures and alternate surface preparations but the results were about the same. Heat treated PS304 coating exceed the strength of the epoxy. Nonetheless the results are still valuable. Any coating which is stronger in tension than the epoxy will likely withstand the stresses encountered in engineered coating applications. Figure 6 shows the effect of the argon heat treatment of PS304. The strengths are higher than the as-deposited samples but only slightly so. Also, there appears to be little effect of substrate on strength. These argon treated samples, like the air treated ones, also failed cohesively in the PS304 coating.

Early on in our research program, it was postulated that the slight substrate variation effect noted for as-deposited coatings was perhaps due to a degree of heat-treating taking place during the high temperatures resulting from plasma spray deposition process. Since Aluminum has a much higher thermal conduct with than stainless steel or Inconel 718 bulk coating temperatures would be expected during deposition. In contrast, the nickel based super alloy, Inconel 718, have relatively poor thermal conductivity leading to high surface and substrate temperatures during coating deposition. This theory would explain the differences in PS304 as-deposited strength.

To examine this theory, coating deposition experiments were performed with thermocouples embedded into the surface and near surface of the coupons. Temperatures were monitored during the Plasmaspraying process and a typical result is shown in figure 7. The jagged nature of the trace is a direct consequence of the back and forth motion of the plasma spray gun in which many passes are made to build up the thick 0.010 in. coating. Not withstanding, the maximum temperature recorded during these trials was only about $300{ }^{\circ} \mathrm{C}$, far lower that the $500{ }^{\circ} \mathrm{C}$ temperature needed to achieve even modest heat treatments for PS304 (ref. 5). Clearly, an "in-situ" heat treatment of PS304 was not the cause for the observed strength differences.

Another theory to explain the substrate effect is the formation of coating residual thermal stresses caused by a mismatch in thermal expansion between the coating and substrate. To test this theory, aluminum and 304 stainless steel samples were coated while providing either heating or cooling air to the backside of the coupon. By doing this the coating can be forced into residual compression by the substrate (if it is heated) or tension (if it is cooled).

Since PS304, like most cermets, is a fairly brittle material, it will exhibit higher strength while under residual compression when subjected to a tensile load, as encountered in the pull-type adhesion tests. Table IV and figure 8 shows the results. Substrate preheating greatly increased the pull-off strength, and precooling greatly decreased the strength. Following a $24 \mathrm{hr}$ heat treatment in air at $650{ }^{\circ} \mathrm{C}, 304$ stainless steel samples which had been either preheated or precooled during the coating deposition yielded pull-off strengths essentially the same as the baseline heat treated samples which were not heated or cooled. Based upon these tests, it is likely that residual thermal stresses cause the slight variations in PS304 coating strength when deposited on different substrates. This effect is eliminated during heat treatment, which allows stress relaxation to occur. 
To understand what happens to the coating during the heat treatment metallographic cross sections were made. Figures 9 and 10 show cross-sections of heat treated PS304 on different substrate. The upper sample is the heat-treated coating; the lower is the corresponding sample in the un-heat treated condition. Earlier research on PS304 deposited on 13-8Mo stainless steel, heat treated in air showed the formation of a second phase precipitate in the NiCr matrix. This result is repeated in the current study, figure 9(e). Further, all of the coating samples which were heat treated in air show this same second phase precipitate microstructural feature. Measurements of coating thickness indicate that the heat treatment in air results in a thickness growth of between 5 and 10 percent when compared to the un-heat treated control sample (appearing directly below the heat treated coating sample in each photomicrograph). It is plausible to conclude that coating exposure to high temperature air, which results in the formation of the precipitates in the PS304 binder phase, $\mathrm{NiCr}$, is the cause for the observed cohesive strength and dimensional increases.

In most of the cases (substrate materials) studied no other microstructural changes were observed. In two materials, Inconel 718 and Stellite 6B, the metallographic cross sections reveal the formation of an interfacial reaction zone of layer between the PS304 and the substrate in addition to the formation of the second phase precipitates. For these samples (figs. 11 and 12) the measured thickness changes were comparable to the other cases where no interfacial reaction occurred. This suggests that the interfacial reaction is the result of interdiffusion of species from the coating and the substrate. These types of phenomena are common and may actually enhance the coating to substrate bond strength. This enhancement is the basis of diffusion bonded protective coatings widely employed in the gas turbine industry. Since the PS304 cohesive and adhesive strengths for all of the heat-treated samples exceed the epoxy strength the quantitative effects of the interface diffusion observed in Inconel 718 and Stellite 6B remains speculative.

Figure 13 shows cross sections of Ti-6-4 samples coated with PS304. When heat-treated in argon (fig. 13(a)) the coating microstructure remains unchanged but interfacial delamination, possibly the result of chemical reactions between the titanium and the fluorides, is observed. When heat-treated in air (fig. 13(b)) gross interfacial reactions and complete coating delamination occurred. In addition, the second phase precipitate in the PS304 NiCr matrix is readily seen. This shows that the coating microstructural changes are a result of interactions between the heat treatment atmosphere (air) and the coating and are not a substrate effect.

The metallographic cross-sections of the argon heat-treated samples are shown in figure 10. These photomicrographs show that the PS304 following the heat treatment is virtually indistinguishable from the as-deposited PS304. No second phase precipitates nor interfacial reactions are observed. Measurements also show that no coating thickness changes occur as in the air heat-treated case. Clearly oxygen plays a vital role in the observed properties (adhesion/cohesion) and microstructural changes to heattreated PS304.

In a previously published report, the authors investigated the second phase precipitates formed during the air heat treatment(s). In that paper, electron microscopy techniques suggested that the precipitates contained high amounts of chromium plus oxygen and traces of silicon. Additional analyses conducted since that work have included x-ray diffraction and x-ray fluorescence microprobe analyses. No conclusive results have been obtained. However, additional research with coating samples containing only $\mathrm{NiCr}$ and additional detailed study of PS304 cross-sections offer clues to a mechanism for the formation of the precipitates.

Coating samples of pure, plasma sprayed $\mathrm{NiCr}$ were prepared and heat-treated in air or argon at $1200^{\circ} \mathrm{F}$. Adhesion tests were performed and showed that no strengthening effect occurs following the heat treatments in air or argon. Further, cross-sections reveal that no second phase precipitates form even for samples heat-treated in air. Clearly some constituent in PS304 (the $\mathrm{Cr}_{2} \mathrm{O}_{3}, \mathrm{Ag}$ or Fluorides) is playing a role in the formation of the precipitates.

Careful optical observations of PS304 samples heat treated in air (and the corresponding un-heated samples) show that the precipitate formation is closely linked to microstructural proximity of the $\mathrm{NiCr}$ phase and the fluoride constituent. In some regions of the PS304 where inhomongeneties exist, little or no precipitates form. For example, $\mathrm{NiCr}$ pockets surrounded by $\mathrm{Ag}$ or Chrome oxide do not readily segregate 
and exhibit the second phase precipitates. Conversely, where the fluorides are in intimate contact with the $\mathrm{NiCr}$ (which is virtually everywhere in PS304 since the Fluorides amount to over $20 \mathrm{vol} \%$ of the coating) the second phase is always present.

Further research studies are underway to better understand the, perhaps catalytic, role of the fluorides in the formation of the second phase precipitates in the NiCr binder of PS304. In any case, these serendipitous precipitate formations enhance coating strength and seem to create no negative consequences in the performance of PS304. However, in applications where dimensional stability is important, a suitable air heat treatment must be preformed prior to service.

\section{Summary}

The effects of substrate and heat treatment atmosphere on the adhesive/cohesive strength of PS304 were studied. It was discovered that, in general, substrate plays a minor role in coating strength when considering as-deposited, un-heat treated coatings. Except for cases where vigorous interfacial reactions were observed (Aluminum and Titanium alloys) substrate has no effect on the strength of heat-treated PS304 coatings.

The results show that heat-treating in argon gas increases strength by approximately 30 percent. This was attributed to interparticle bonded enhanced by atomic diffusion during the heat treatment. No microstructural changes were observed. Heat treating in air resulted in the formation of a second phase precipitate in the NiCr matrix of the PS304 coating. For most of the substrates, no interfacial reactions were observed. The microstructural changes resulted in a thickness increase of about 5 percent suggesting that the precipitates may be due to oxidation. The coating strength increased nearly two-fold following the heat treatment. All of the air heat-treated coatings exhibit the same microstructural features again suggesting that substrate plays no role in coating strength.

The results corroborate earlier work with the PS304 coating and suggest that an air heat treatment be performed to improve coating strength and ensure dimensional stability. Further work is needed to fully understand the mechanism(s) for the observed microstructural and strength changes.

\section{References}

1. DellaCorte, C.; and Edmonds, B.J.: Preliminary Evaluation of PS300: A New Self-Lubricating High Temperature Composite Coating for Use to $800^{\circ} \mathrm{C}$. NASA TM-107056, November 1995.

2. DellaCorte, C.; and Edmonds, B.J.: U.S. Patent \# 586618, February 1999.

3. DellaCorte, C.; and Fellenstein, J.A.: The Effect of Compositional Tailoring on the Thermal Expansion and Tribological Properties of PS300: A Solid Lubricant Composite Coating. NASA TM-107332 and Tribology Transactions, vol. 40, no. 2, pp. 639-642, 1997.

4. DellaCorte, C.: Performance and Durability of High Temperature Foil Air Bearing for Oil-Free Turbomachinery. NASA/TM-1999-209187 and Tribology Transactions, vol. 43, no. 4, 2000.

5. DellaCorte, C.; Edmonds, B.J.; and Benoy, P.A.: Thermal Processing Effects on the Adhesive Strength of PS304 High Temperature Solid lubricant Coatings. NASA/TM-2001-210944. 
TABLE I.-COMPOSITION AND SELECTED PROPERTIES OF PS304

\begin{tabular}{|l|c|l|}
\hline \multicolumn{1}{|c|}{ Constituent/Property } & $\mathrm{wt} \%$ & \multicolumn{1}{c|}{ Function/Value } \\
\hline $\mathrm{NiCr}^{\mathrm{a}}$ & 60 & matrix-binder \\
\hline $\mathrm{Cr}_{2} \mathrm{O}_{3}$ & 20 & hardener phase \\
\hline $\mathrm{Ag}$ & 10 & low temperature lubricant \\
\hline $\mathrm{BaF}_{2} / \mathrm{CaF}_{2}{ }^{\mathrm{b}}$ & 10 & high temperature lubricant \\
\hline $\mathrm{Thermal} \mathrm{expansion} \mathrm{CTE}^{\mathrm{N}}$ & -- & $12.4 \times 10^{-6} /{ }^{\circ} \mathrm{C}$ \\
\hline Density & -- & $\sim 5.3 \mathrm{~g} / \mathrm{cc}$ \\
\hline$\rho$ hardness & -- & 30 to $34 \mathrm{RC}$ \\
\hline
\end{tabular}

${ }^{a} \mathrm{Ni} / \mathrm{Cr}$ ratio is $80 / 20$ by $\mathrm{wt} \%$

${ }^{\mathrm{b}} \mathrm{BaF}_{2} / \mathrm{CaF}_{2}$ ratio is $62 / 38$ by $\mathrm{wt} \%$

TABLE II.-NOMINAL COMPOSITION AND SELECTED PROPERTIES OF COATING SUBSTRATES

\begin{tabular}{|c|c|c|c|c|}
\hline Name & Alloy type & $\begin{array}{l}\text { Nominal composition, } \\
\qquad \mathrm{wt} \%\end{array}$ & $\begin{array}{c}\text { Thermal } \\
\text { conductivity, } \\
\text { k } \\
\mathrm{W} / \mathrm{m}-{ }^{\circ} \mathrm{k}\end{array}$ & $\begin{array}{c}\text { Thermal } \\
\text { expansion, } \\
\text { CTE } \\
\times 10^{-6} /{ }^{\circ} \mathrm{C}\end{array}$ \\
\hline Inconel 718 & $\begin{array}{l}\text { Nickel base } \\
\text { superalloy }\end{array}$ & $53 \mathrm{Ni}, 18 \mathrm{Cr}, 17 \mathrm{Fe}, 5 \mathrm{Nb}, 3 \mathrm{Mo}, 1 \mathrm{Co}, 1 \mathrm{Ti}$ & 11.4 & 14 \\
\hline Stellite 6B & $\begin{array}{l}\text { Cobalt base } \\
\text { superalloy }\end{array}$ & $\begin{array}{c}54 \mathrm{Co}, 29 \mathrm{Cr}, 3 \mathrm{Fe}, 3 \mathrm{Ni}, 5 \mathrm{~W}, 1.5 \mathrm{Mo}, \\
1 \mathrm{C}, 1 \mathrm{Mn}\end{array}$ & 14.9 & 13.5 \\
\hline 304 stainless steel & $\begin{array}{l}\text { Austenitic } \\
\text { stainless steel }\end{array}$ & $71 \mathrm{Fe}, 19 \mathrm{Cr}, 10 \mathrm{Ni}, 0.1 \mathrm{C}$ & 13.8 & 16 \\
\hline 410 stainless steel & $\begin{array}{l}\text { Martensitic } \\
\text { stainless steel }\end{array}$ & $87 \mathrm{Fe}, 13 \mathrm{Cr}, 0.2 \mathrm{C}$ & 25.1 & 10 \\
\hline 13-8Mo PM & $\begin{array}{l}\text { Precipitation } \\
\text { hardened } \\
\text { stainless steel }\end{array}$ & $76 \mathrm{Fe}, 13 \mathrm{Cr}, 8 \mathrm{Ni}, 2 \mathrm{Mo}, 1 \mathrm{Al}$ & 15.2 & 11 \\
\hline Greek Ascolloy & High alloy steel & $82 \mathrm{Fe}, 13 \mathrm{Cr}, 2 \mathrm{Ni}, 3 \mathrm{~W}, 0.2 \mathrm{C}$ & 21 & 10 \\
\hline Ti-6-4 & Titanium alloy & $90 \mathrm{Ti}, 6 \mathrm{Al}, 4 \mathrm{~V}$ & 6.9 & 10 \\
\hline $6061 \mathrm{Al}$ & Aluminum alloy & $98 \mathrm{Al}, 0.6 \mathrm{Si}, 0.3 \mathrm{Mn}, 1 \mathrm{Mg}, 0.2 \mathrm{Cr}$ & 167 & 23 \\
\hline
\end{tabular}


TABLE III.-PULL-OFF COATING STRENGTH DATA SUMMARY

\begin{tabular}{|c|c|c|c|c|}
\hline \multirow{2}{*}{ Substrate material } & \multicolumn{3}{|c|}{ Heat treatment } & \multirow{2}{*}{ Comments } \\
\hline & None & Argon & Air HT & \\
\hline \multirow{2}{*}{ Inconel 718} & $2890 \pm 175$ psi & $3935 \pm 186$ psi & $4869 \pm 354$ psi & \\
\hline & $19.9 \pm 1.2 \mathrm{MPa}$ & $27.1 \pm 1.3 \mathrm{MPa}$ & $33.6 \pm 2.4 \mathrm{MPa}$ & \\
\hline \multirow{2}{*}{ Stellite 6B } & $2789 \pm 213$ & $3677 \pm 136$ & $4945 \pm 329$ & \multirow[t]{2}{*}{12 samples of each } \\
\hline & $19.2 \pm 1.5$ & $25.4 \pm 0.9$ & $34.1 \pm 2.3$ & \\
\hline \multirow{2}{*}{304 stainless steel } & $2542 \pm 362$ & $3627 \pm 237$ & $5397 \pm 225$ & \\
\hline & $17.5 \pm 2.5$ & $25 \pm 1.6$ & $37.2 \pm 1.6$ & \\
\hline \multirow{2}{*}{410 stainless steel } & $2713 \pm 62$ & $3229 \pm 386$ & $5329 \pm 331$ & \\
\hline & $18.7 \pm 0.4$ & $22.3 \pm 2.7$ & $36.7 \pm 2.3$ & \\
\hline \multirow{2}{*}{ 13.8 Mo PH } & $2869 \pm 147$ & $3023 \pm 269$ & $4605 \pm 434$ & \\
\hline & $19.8 \pm 1.0$ & $20.8 \pm 1.8$ & $31.8 \pm 3.0$ & \\
\hline \multirow{2}{*}{ Greek Ascolloy } & $2619 \pm 129$ & $3692 \pm 204$ & $5130 \pm 235$ & \\
\hline & $18.1 \pm 0.9$ & $25.5 \pm 1.4$ & $35.4 \pm 1.6$ & \\
\hline \multirow{2}{*}{ Ti-6-4 } & $2801 \pm 121$ & -- & -- & \multirow{2}{*}{$\begin{array}{l}\text { coating delaminated upon } \\
\text { heat treatment }\end{array}$} \\
\hline & $19.3 \pm 0.8$ & -- & -- & \\
\hline \multirow{2}{*}{$6061 \mathrm{Al}$} & $2366 \pm 292$ & -- & -- & \multirow{2}{*}{$\begin{array}{l}\text { coating delaminated from } \\
\text { heat treatment }\end{array}$} \\
\hline & $16.3 \pm 2.0$ & -- & -- & \\
\hline Average psi & $2699 \pm 180$ & $3531 \pm 337$ & $5046 \pm 299$ & \\
\hline Average $\mathrm{MPa}$ & $18.6 \pm 1.2$ & $24.3 \pm 2.3$ & $34.8 \pm 2.1$ & \\
\hline
\end{tabular}

TABLE IV.-PULL-OFF DATA SUMMARY OF PREHEATED/PRECOOLED COATED SUBSTRATES

\begin{tabular}{|c|c|c|c|}
\hline Substrate material & Substrate condition* & Heat treatment & Pull-off strength \\
\hline \multirow{2}{*}{$6061 \mathrm{Al}$} & Ambient & None & $\begin{array}{c}2366 \pm 292 \mathrm{psi} \\
16.3 \pm 20 \mathrm{MPa}\end{array}$ \\
\hline \multirow{2}{*}{$6061 \mathrm{Al}$} & Preheated & None & $\begin{array}{c}3477 \pm 149 \\
23.8 \pm 1.0\end{array}$ \\
\hline \multirow{2}{*}{$6061 \mathrm{Al}$} & Precooled & None & $\begin{array}{c}1372 \pm 225 \\
9.5 \pm 1.6\end{array}$ \\
\hline 304 stainless steel & Ambient & None & $\begin{array}{c}2542 \pm 362 \\
17.5 \pm 2.5\end{array}$ \\
\hline \multirow{2}{*}{304 stainless steel } & Preheated & None & $\begin{array}{c}4178 \pm 154 \\
28.8 \pm 1.1\end{array}$ \\
\hline \multirow{2}{*}{304 stainless steel } & Precooled & None & $\begin{array}{c}2178 \pm 549 \\
15.0 \pm 3.8\end{array}$ \\
\hline \multirow{2}{*}{304 stainless steel } & Preheated & $650^{\circ} \mathrm{C} / 24 \mathrm{hr}$ in air & $\begin{array}{c}5639 \pm 369 \\
38.8 \pm 2.5\end{array}$ \\
\hline \multirow{2}{*}{304 stainless steel } & Precooled & $650^{\circ} \mathrm{C} / 24 \mathrm{hr}$ in air & $\begin{array}{c}5546 \pm 272 \\
38.2 \pm 1.9\end{array}$ \\
\hline \multirow{2}{*}{304 stainless steel } & \multirow{2}{*}{ Ambient } & $650^{\circ} \mathrm{C} / 24 \mathrm{hr}$ in air & $\begin{array}{c}5397 \pm 225 \\
37.2 \pm 1.6\end{array}$ \\
\hline
\end{tabular}

*Ambient means substrate temperature was not controlled, preheat temperature was $260^{\circ} \mathrm{C}$, precooled means $25^{\circ} \mathrm{C}$ air jet impinged on sample backside during coating deposition. 


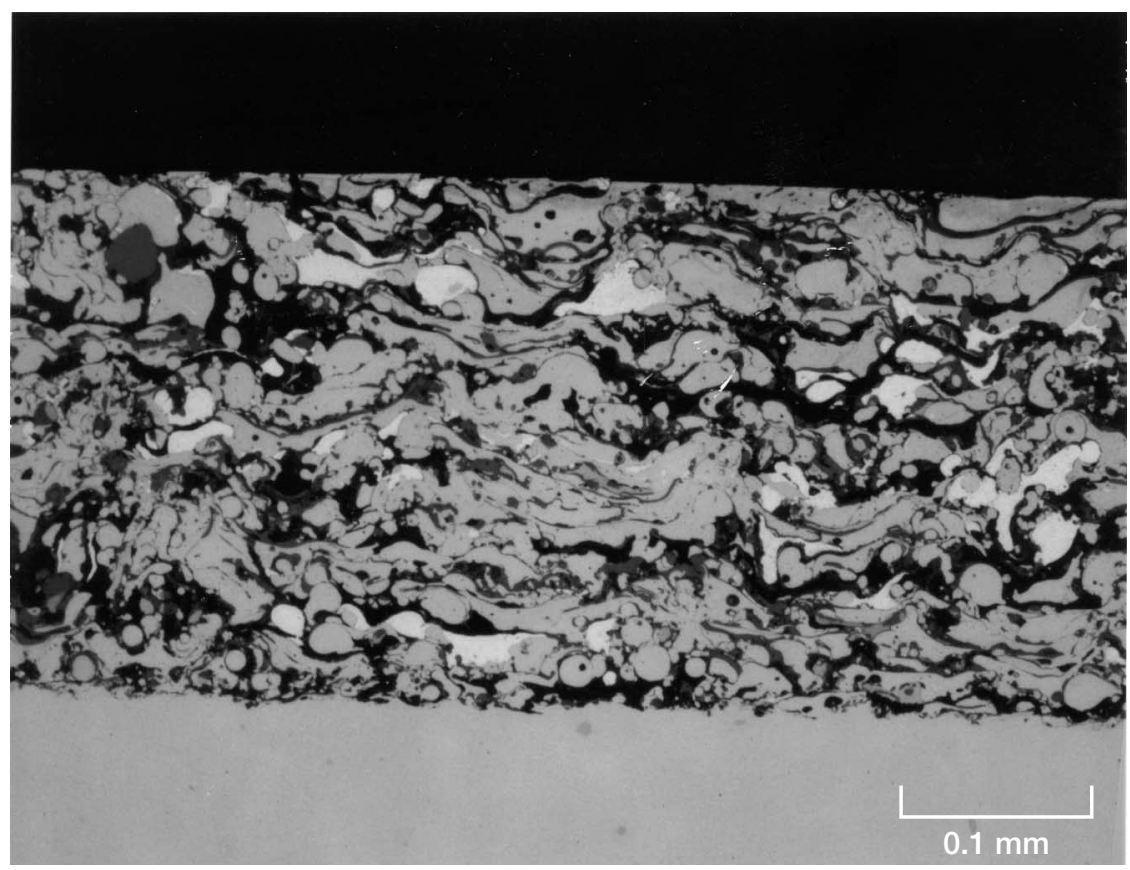

Figure 1.-Typical PS304 cross-section photomicrograph.

Step 1

PS304 coated coupon

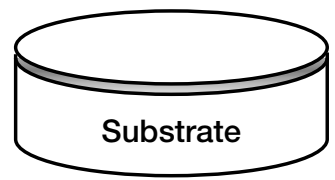

Step 3

Thermal process

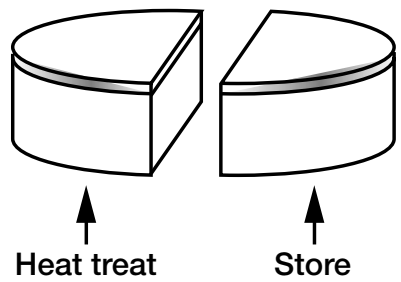

Step 5

Metallographically mount and polish

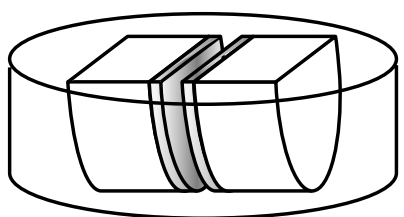

Figure 2.-Schematic representation of cross-sectional mounting technique used to prepare sample.
Step 2

Wire (EDM) cut

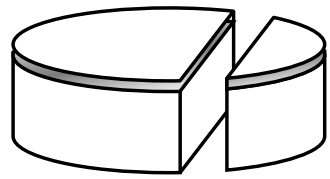

Step 4

Reassemble sample and fold
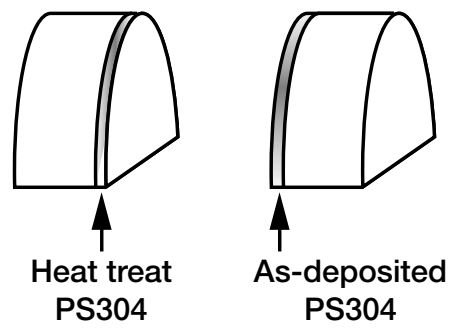

Step 6

Microscopic comparison Top view

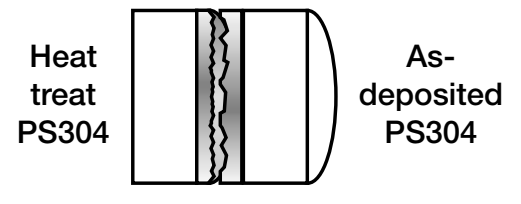




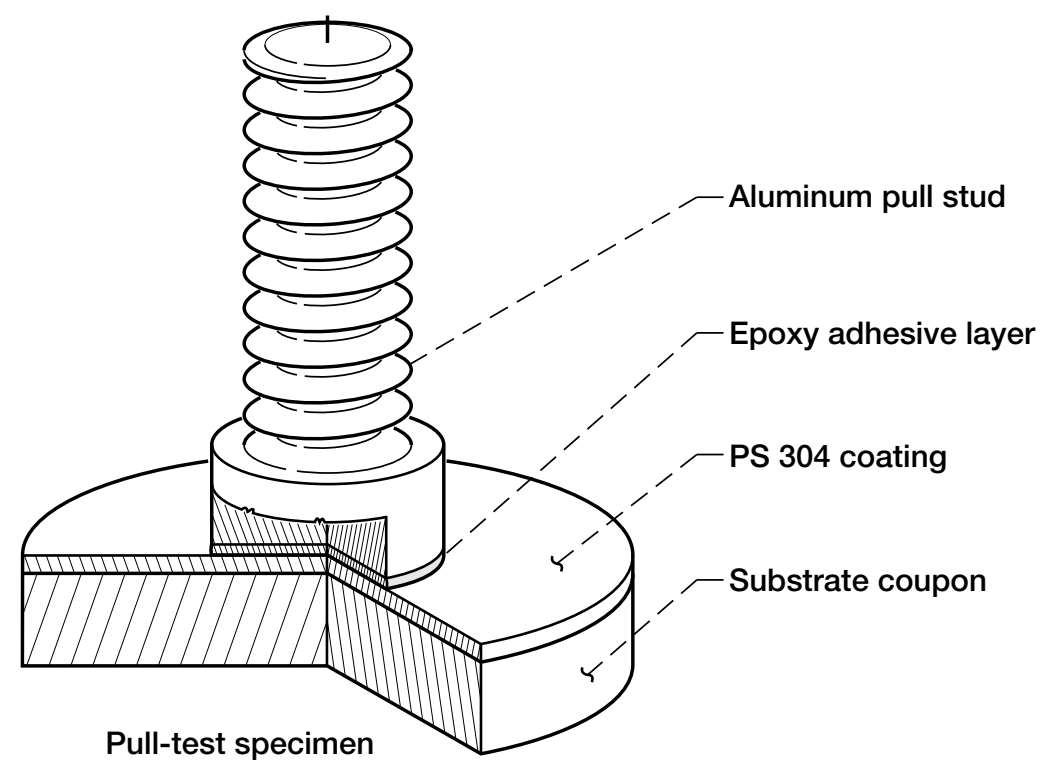

Pull-test specimen

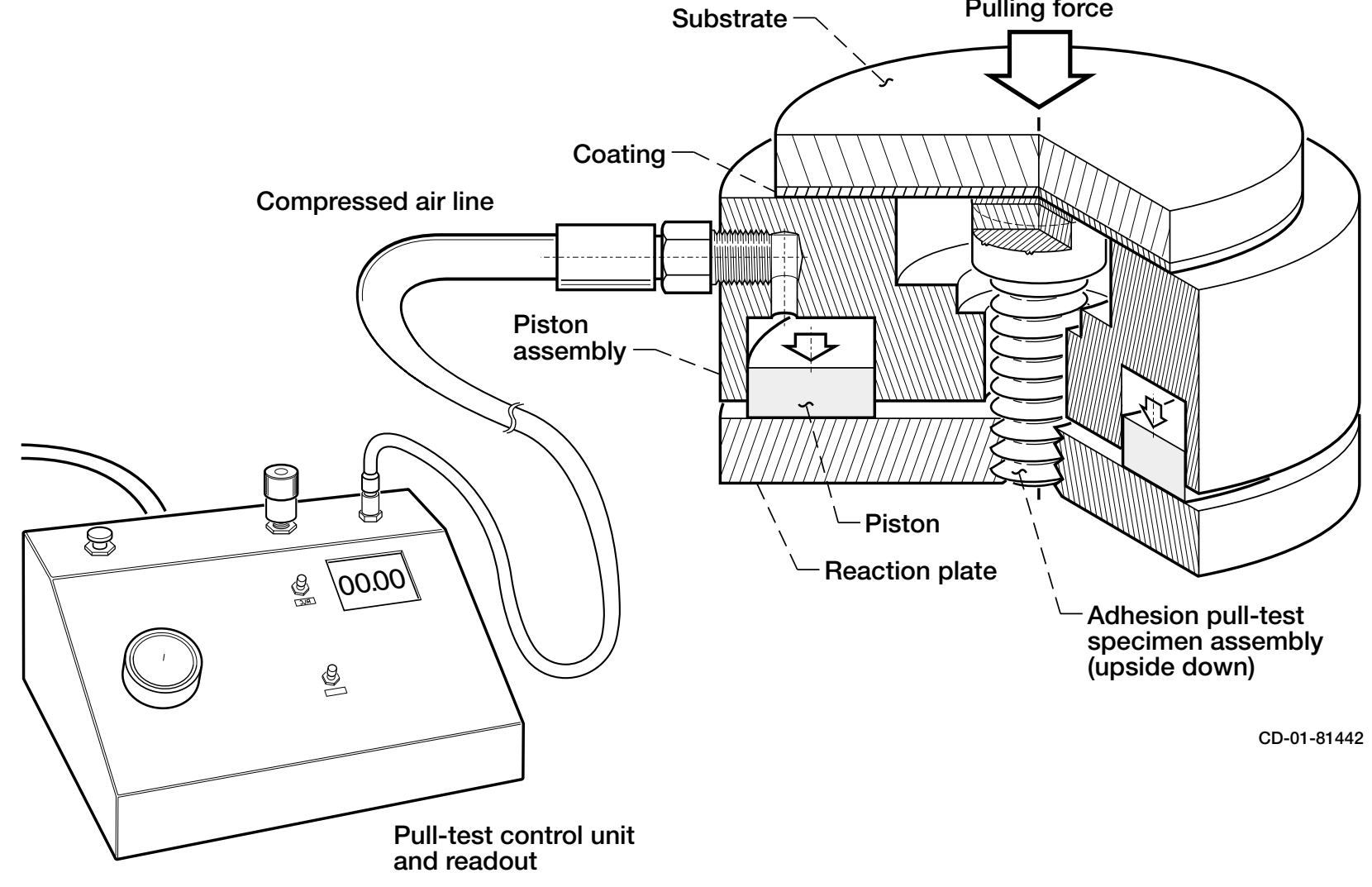

Figure 3.-Adhesion pull-test specimen assembly and system. 


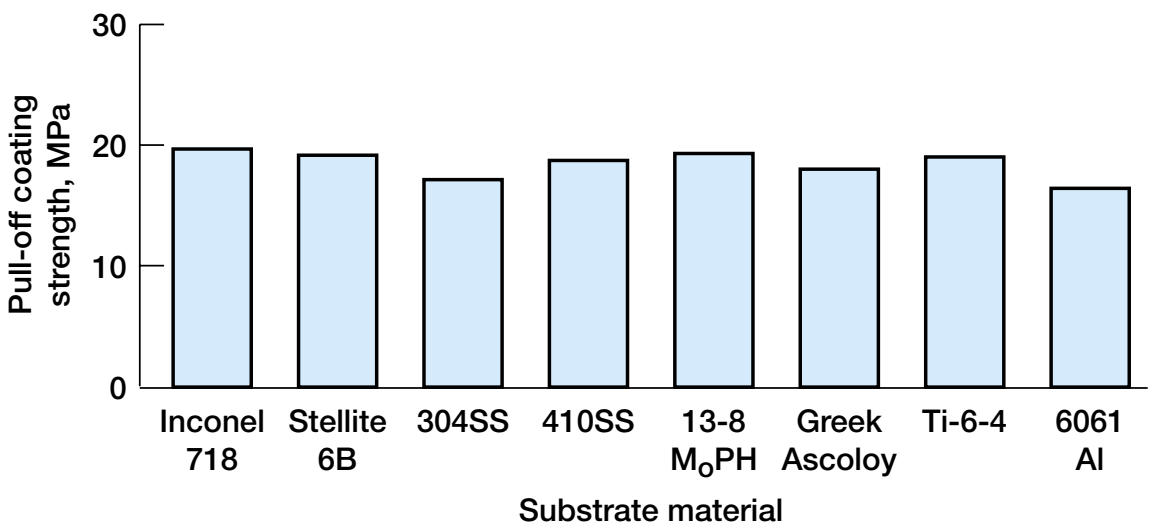

Figure 4.-Coating pull-off strength for the as-deposited (no heat treatment) PS304 on various substrates.

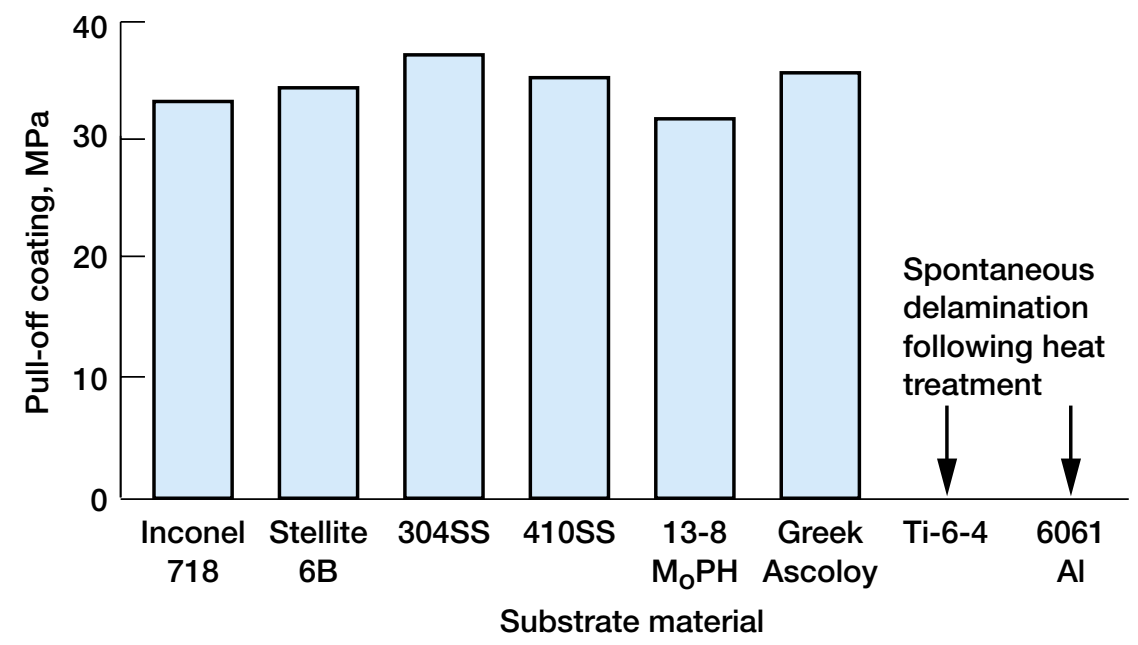

Figure 5.-Coating pull-off strength for the air $\left(100 \mathrm{hr}\right.$ at $\left.650{ }^{\circ} \mathrm{C}\right)$ heat treated PS304 on various substrates. Ti-6-4 and 6061 Al samples delaminated from heat treatment.

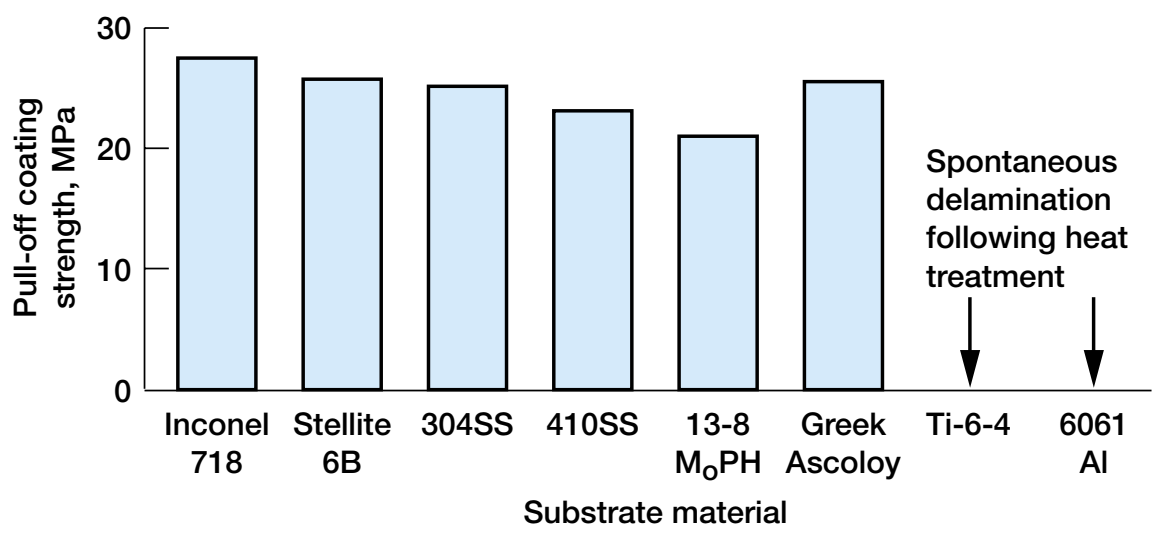

Figure 6.-Coating pull-off strength for the argon $\left(100 \mathrm{hr}\right.$ at $\left.650{ }^{\circ} \mathrm{C}\right)$ heat treated PS304 on various substrates. Ti-6-4 and 6061 Al samples delaminated from heat treatment. 


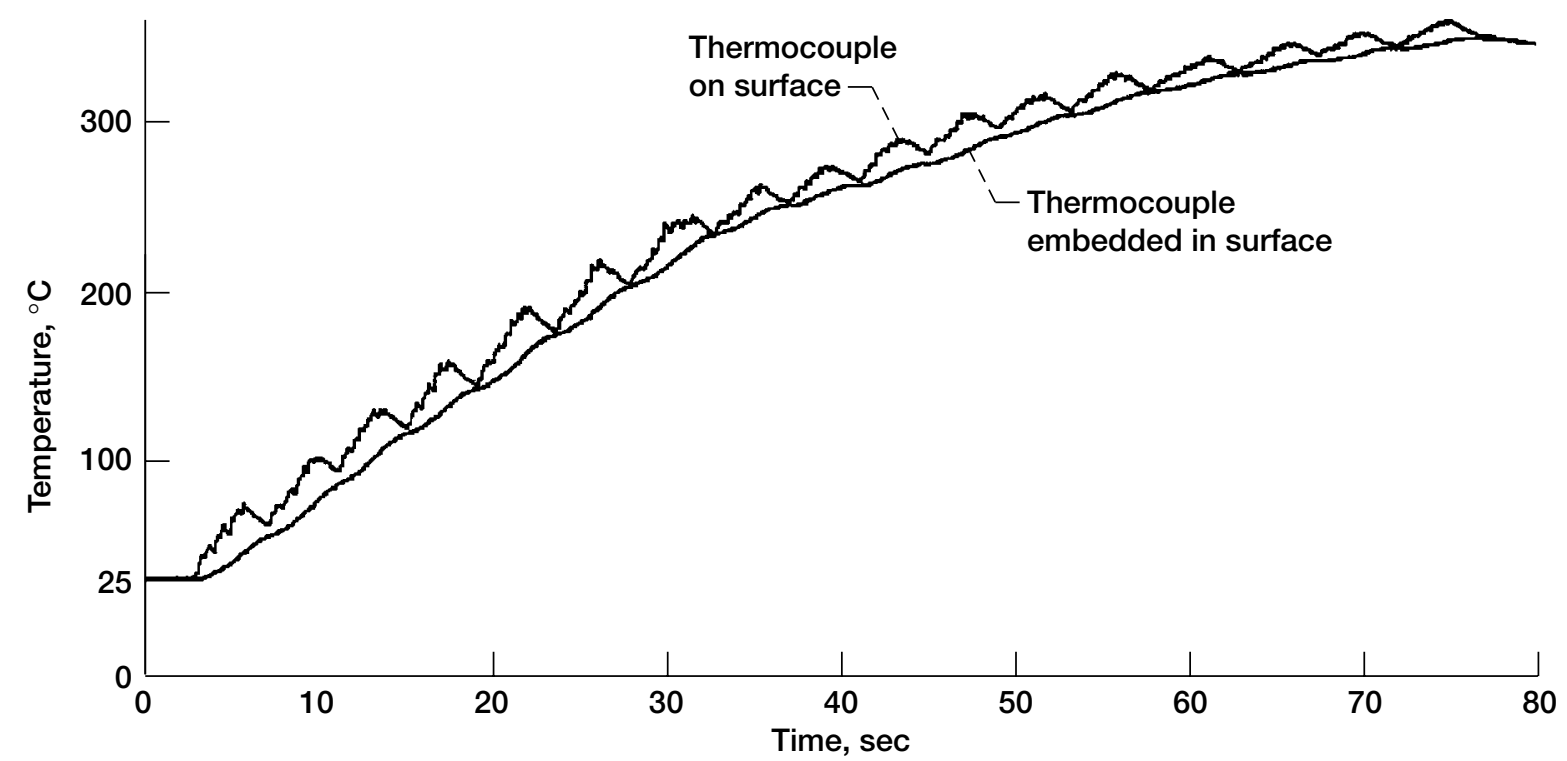

Figure 7.-Substrate temperature during plasma spray deposition PS304 coating on 410 stainless steel.

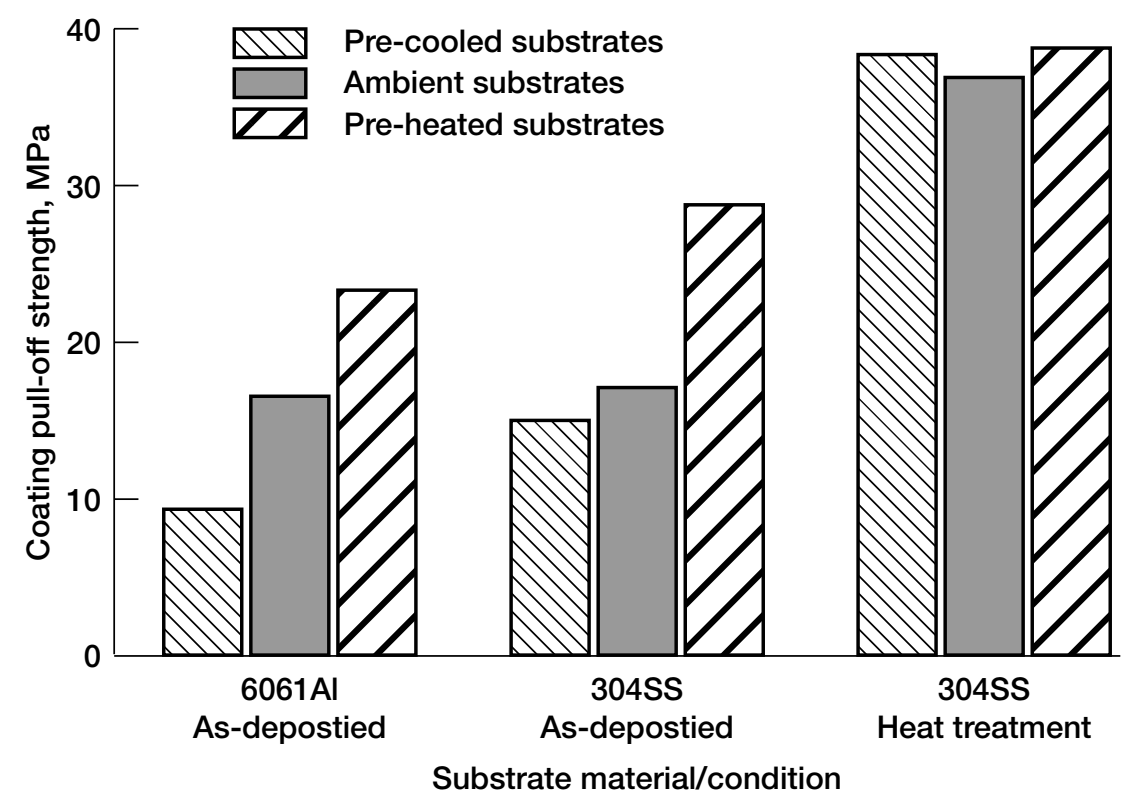

Figure 8.-Coating pull-off strengths for the pre-heated $\left(260^{\circ} \mathrm{C}\right)$ and pre-cooled $\left(25^{\circ} \mathrm{C}\right)$ air impringement) substrates. 

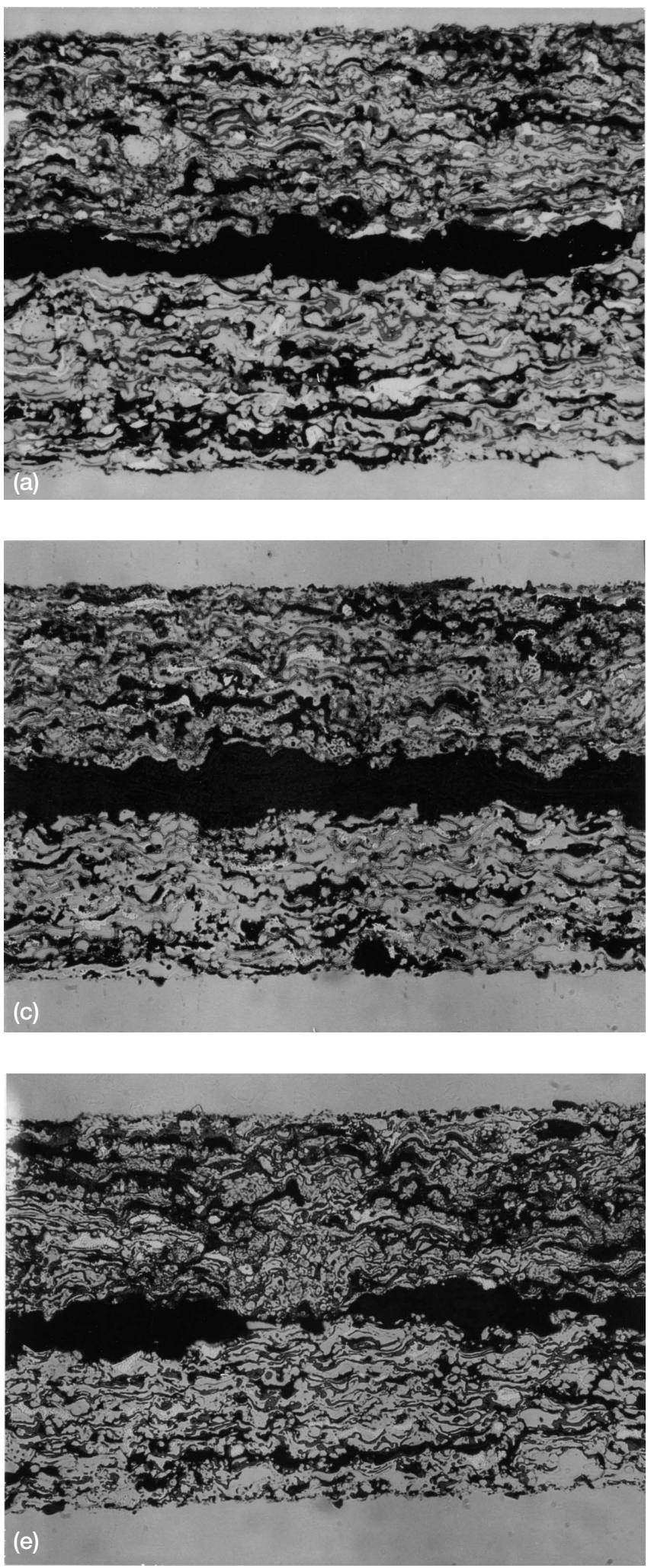
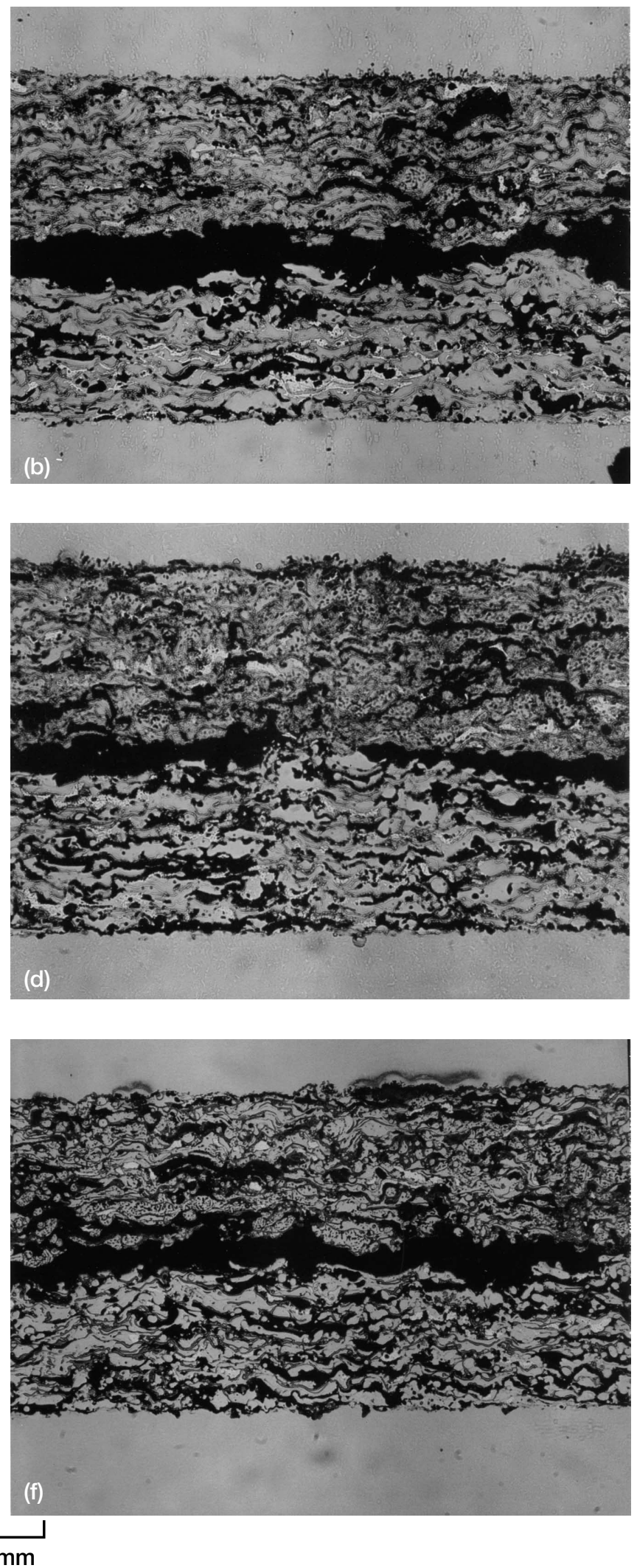

Figure 9.-Metallographic cross-sections of PS304 coatings on various substrates. Upper coating heat treated in air at $650{ }^{\circ} \mathrm{C}$ for $100 \mathrm{hr}$ lower coating in as-deposited condition. (a) Inconel 718. (b) Stellite 6B. (c) 304 Stainless steel. (d) 410 Stainless steel. (e) $13-8 \mathrm{MoPH}$ stainless steel. (f) Greek Ascoloy steel. 

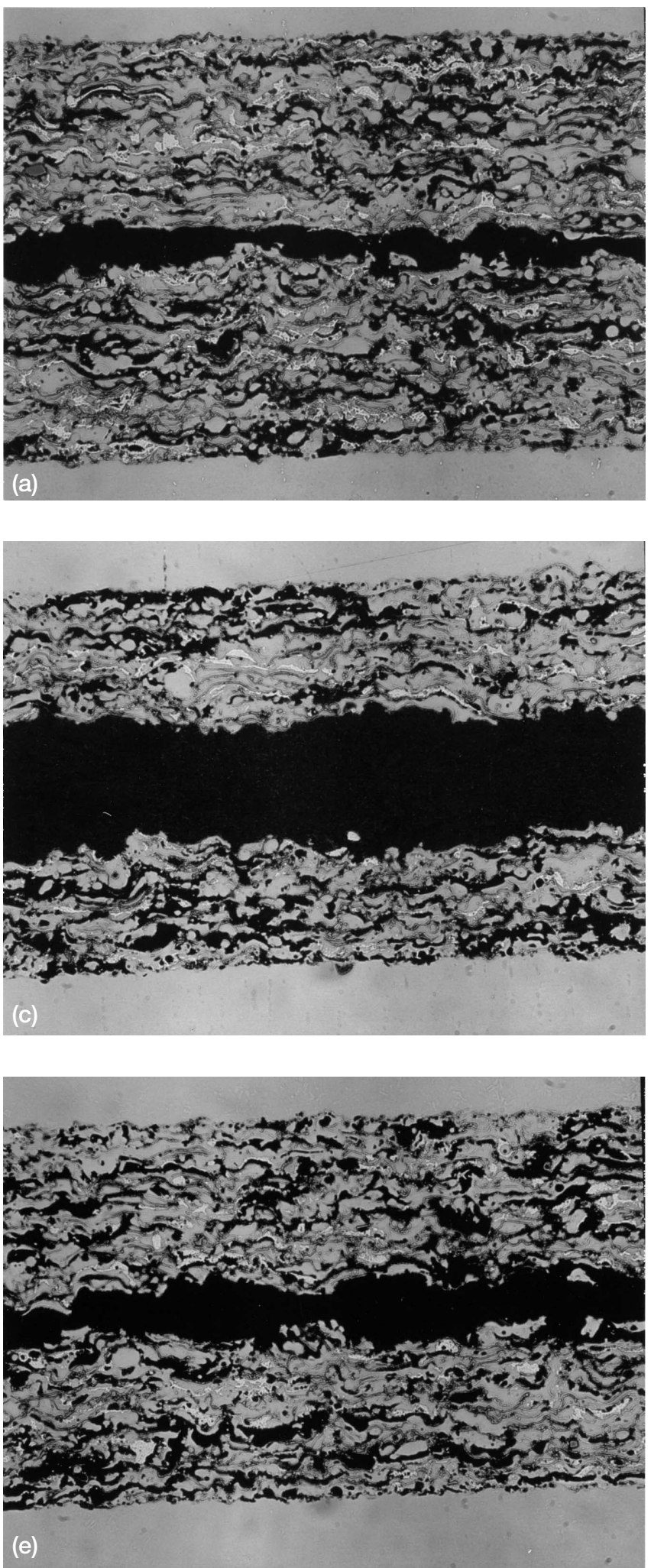
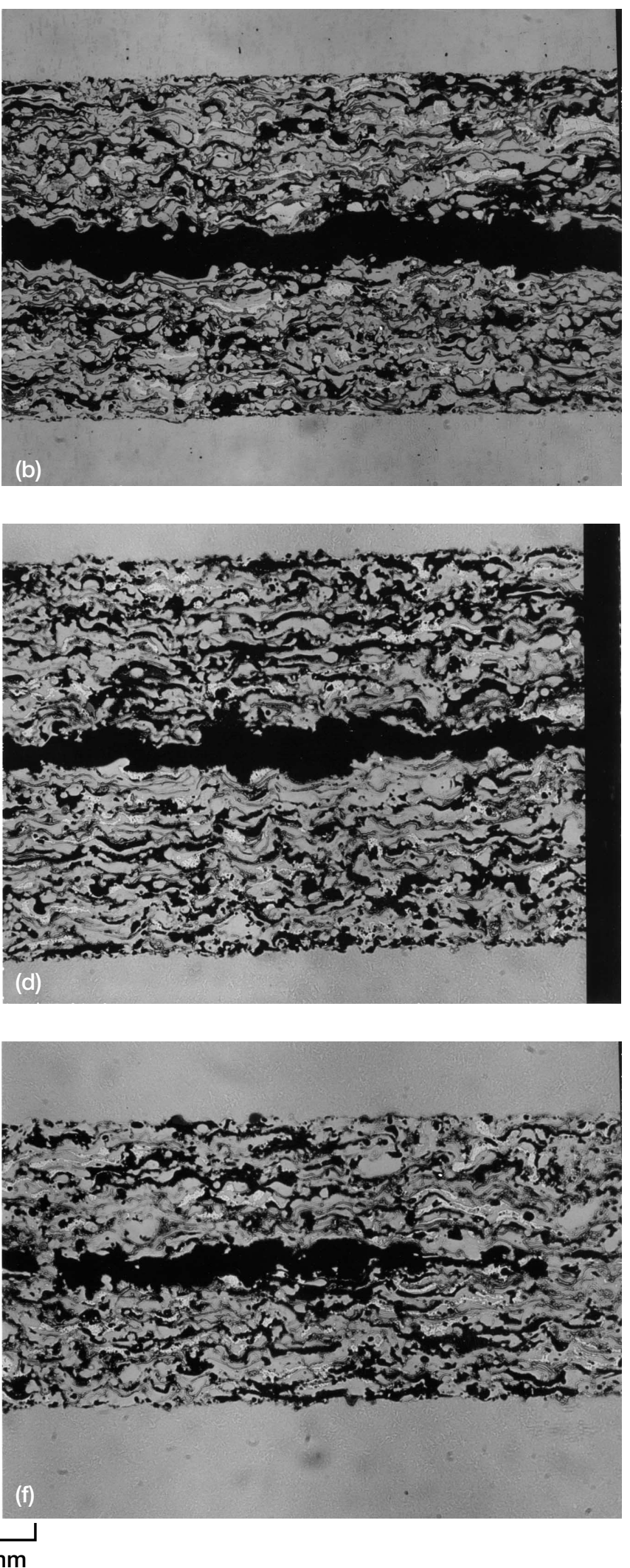

Figure 10.-Metallographic cross-sections of PS304 coatings on various substrates. Upper coating heat treated in argon at $650{ }^{\circ} \mathrm{C}$ for $100 \mathrm{hr}$ lower coating in as-deposited condition. (a) Inconel 718. (b) Stellite 6B. (c) 304 Stainless steel.

(d) 410 Stainless steel. (e) 13-8 MoPH stainless steel. (f) Greek Ascoloy high-alloy steel. 

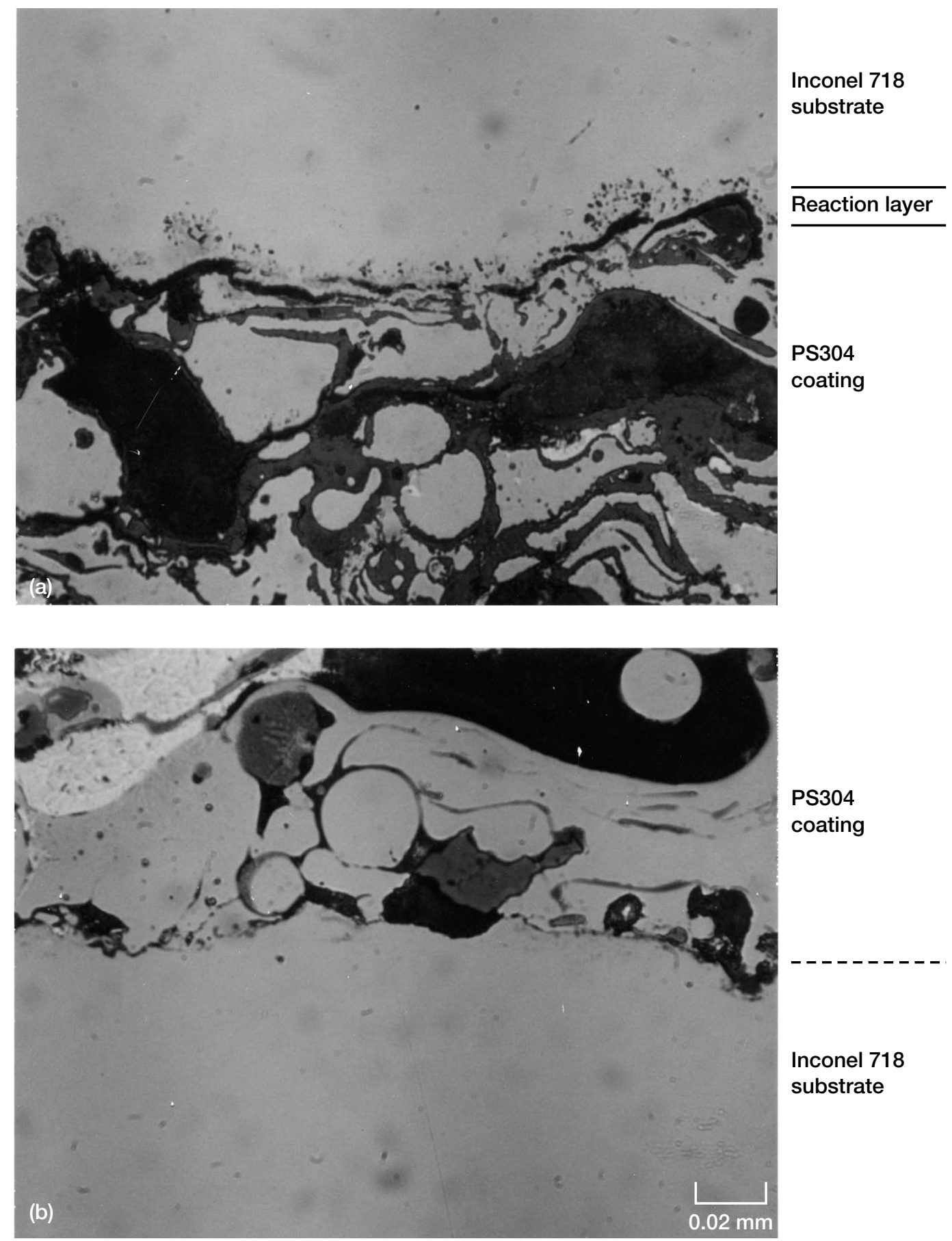

PS304

coating

Inconel 718

substrate

Figure 11.-PS304 coated Inconel 718 sample. (a) Heat treated sample showing reaction layer (dark spots). (b) As deposited (no-heat treatment) shown for comparison. 

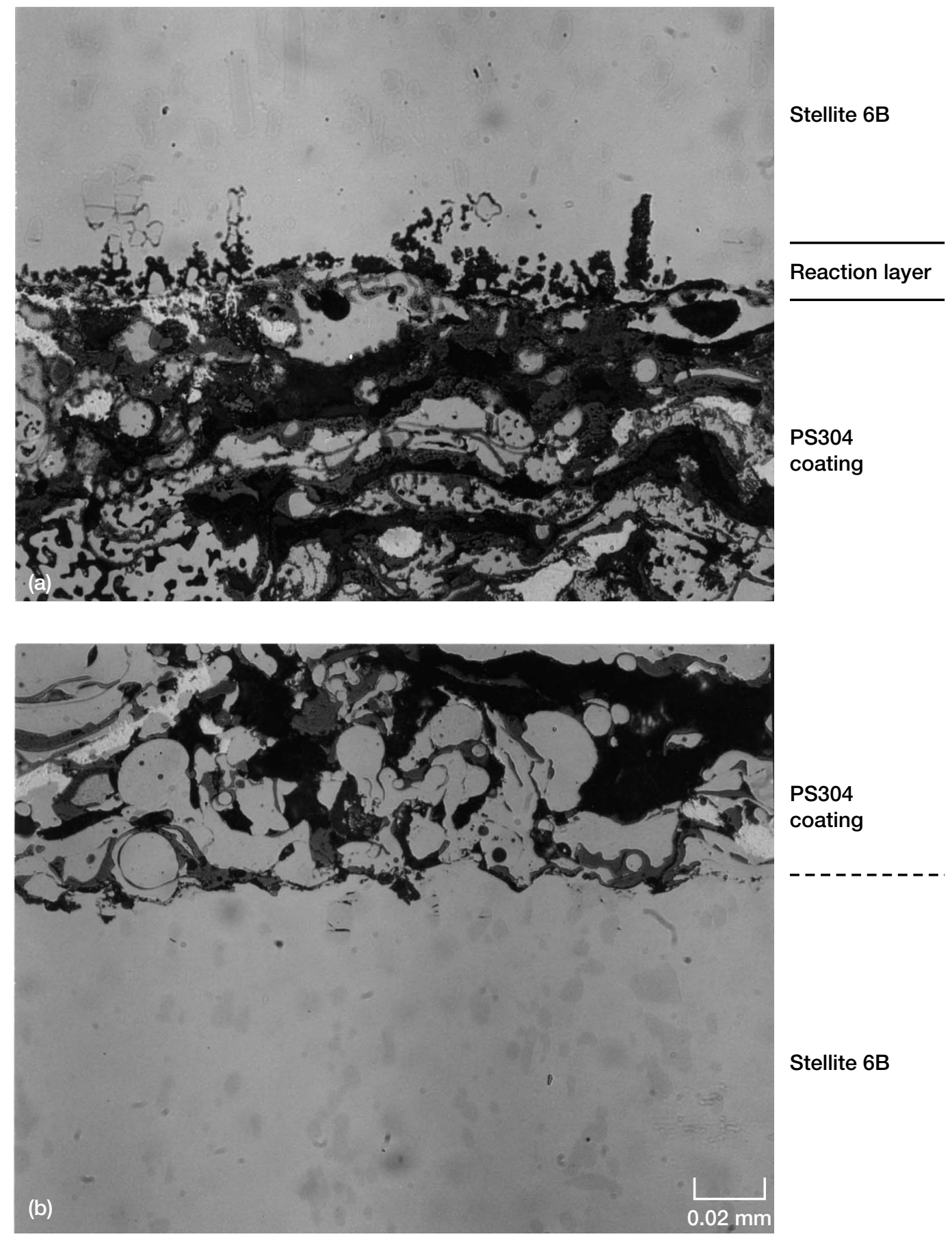

PS304

coating

Stellite 6B

Figure 12.-PS304 coated Stellite 6B sample. (a) Heat treated sample showing interfacial reaction region (dark spots). (b) As deposited (no-heat treatment) shown for comparison. 


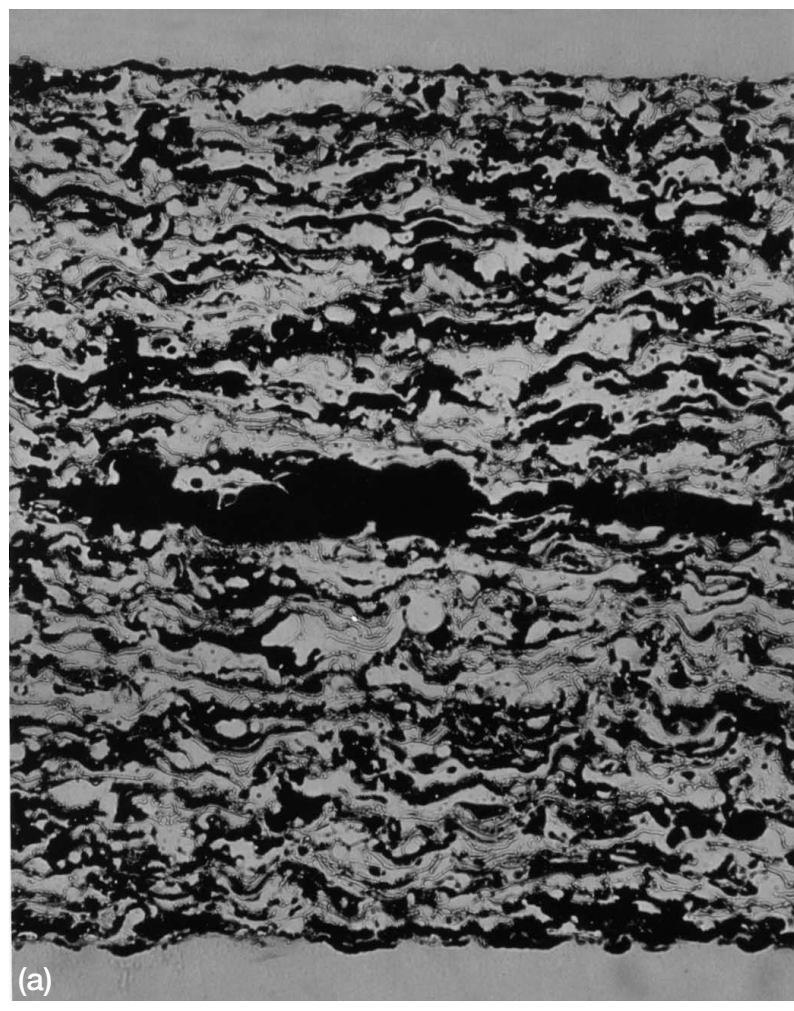

Ti-6-4

substrate

Argon

heat treated

PS304

As-deposited

PS304

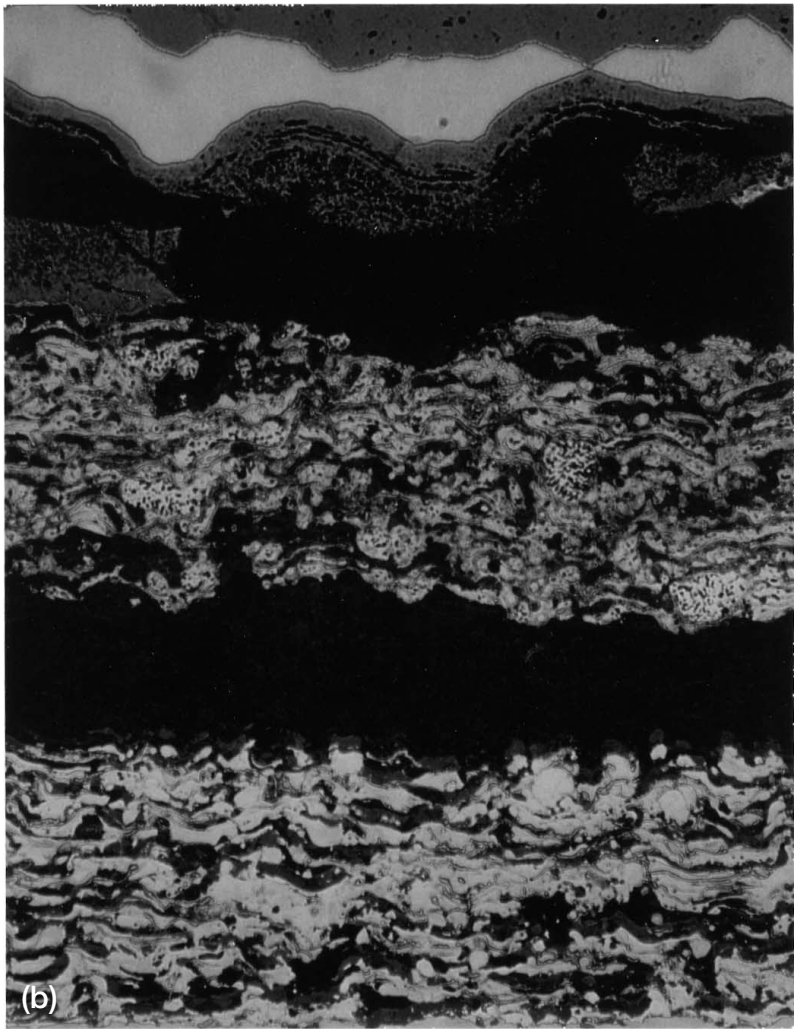

Gross interfacial reaction

layer and delamination

PS304

heat treated

in air

As-deposited

PS304

\section{L}

Figure 13.-PS304 coated Ti-6-4 sample. (a) Argon heat treated shows no second phase but delamination at substrate. (b) Air heat treated shows second phase precipitates and gross interfacial reaction layer and delamination. 
Public reporting burden for this collection of information is estimated to average 1 hour per response, including the time for reviewing instructions, searching existing data sources, gathering and maintaining the data needed, and completing and reviewing the collection of information. Send comments regarding this burden estimate or any other aspect of this collection of information, including suggestions for reducing this burden, to Washington Headquarters Services, Directorate for Information Operations and Reports, 1215 Jefferson Davis Highway, Suite 1204, Arlington, VA 22202-4302, and to the Office of Management and Budget, Paperwork Reduction Project (0704-0188), Washington, DC 20503.

\begin{tabular}{|l|l|l}
\hline 1. AGENCY USE ONLY (Leave blank) & $\begin{array}{c}\text { 2. REPORT DATE } \\
\text { September } 2002\end{array}$ & $\begin{array}{r}\text { 3. REPORT TYPE AND DATES COVERED } \\
\text { Technical Memorandum }\end{array}$ \\
\hline
\end{tabular}

4. TITLE AND SUBTITLE

5. FUNDING NUMBERS

The Effects of Substrate Material and Thermal Processing Atmosphere on the

Strength of PS304: A High Temperature Solid Lubricant Coating

6. AUTHOR(S)

Christopher DellaCorte

WU-708-18-13-00

7. PERFORMING ORGANIZATION NAME(S) AND ADDRESS(ES)

National Aeronautics and Space Administration

John H. Glenn Research Center at Lewis Field

Cleveland, Ohio 44135-3191

8. PERFORMING ORGANIZATION

REPORT NUMBER

E-13251

9. SPONSORING/MONITORING AGENCY NAME(S) AND ADDRESS(ES)

10. SPONSORING/MONITORING

AGENCY REPORT NUMBER

National Aeronautics and Space Administration

Washington, DC 20546-0001

NASA TM-2002-211483

11. SUPPLEMENTARY NOTES

Responsible person, Christopher DellaCorte, organization code 5960, 216-433-6056.

12a. DISTRIBUTION/AVAILABILITY STATEMENT

12b. DISTRIBUTION CODE

Unclassified - Unlimited

Subject Category: 23

Distribution: Nonstandard

Available electronically at http://gltrs.grc.nasa.gov/GLTRS

This publication is available from the NASA Center for AeroSpace Information, 301-621-0390.

13. ABSTRACT (Maximum 200 words)

PS304, a plasma spray deposited solid lubricant coating developed for high temperature sliding contacts was deposited on nine different substrate metals, heat treated at $650{ }^{\circ} \mathrm{C}$ in either air or argon and subsequently tested for strength using a commercially available pull-off adhesion test. Some samples were examined metallographically to help elucidate and explain the results. As deposited coatings exhibit pull-off strengths typically between 16 and $20 \mathrm{MPa}$ with failure occurring (cohesively) within the coating. Heat treatment in argon at $650{ }^{\circ} \mathrm{C}$ results in a slight increase in coating (cohesive) strength of about 30 percent to 21 to $27 \mathrm{MPa}$. Heat treatment in air at $650{ }^{\circ} \mathrm{C}$ results in a dramatic increase in strength to over $30 \mathrm{MPa}$, exceeding the strength of the epoxy used in the pull test. Cross section metallographic analyses show that no microstructural coating changes occur following the argon heat treatments, however, exposure to air at $650{ }^{\circ} \mathrm{C}$ gives rise to the formation of a second chromium-rich phase precipitate within the PS304 NiCr constituent which provides a strengthening effect and a slight ( $\sim 5$ percent) coating thickness increase. Subsequent heat treatments do not result in any further coating changes. Based upon these studies, PS304 is a suitable coating for use on a wide variety of high temperature substrates and must be heat treated following deposition to enhance strength and ensure dimensional stability.

14. SUBJECT TERMS

Materials; Coatings; Solid lubrication

15. NUMBER OF PAGES

22

16. PRICE CODE

20. LIMITATION OF ABSTRACT

\begin{tabular}{c|c|c}
$\begin{array}{l}\text { 17. SECURITY CLASSIFICATION } \\
\text { OF REPORT }\end{array}$ & $\begin{array}{c}\text { 18. SECURITY CLASSIFICATION } \\
\text { OF THIS PAGE } \\
\text { Unclassified }\end{array}$ & $\begin{array}{c}\text { 19. SECURITY CLASSIFICATION } \\
\text { OF ABSTRACT } \\
\text { Unclassified }\end{array}$
\end{tabular}

NSN 7540-01-280-5500
Standard Form 298 (Rev. 2-89)

Prescribed by ANSI Std. Z39-18 298-102 